\title{
$\beta$-Turn-Like Conformation and Side Chain Interactions of Aspartic Acid-Containing Dipeptides
}

\author{
Hiroshi ISHII, Yoshio INOUE, and Riichirô CHÛJÔ \\ Department of Polymer Chemistry, Tokyo Institute of Technology, \\ Ookayama 2-chome, Meguro-ku, Tokyo 152, Japan
}

(Received September 1, 1983)

\begin{abstract}
Conformation of Asp-containing dipeptides of the general formulae: Ac-Asp$\mathrm{X}-\mathrm{NHMe}$ and Ac-X-Asp-NHMe (X=Ser, Lys, Asp, and Tyr $)$ in solution were investigated using ${ }^{1} \mathrm{H}$ and ${ }^{13} \mathrm{C}$ NMR spectroscopy. The dominant formation of a $\beta$-turn-like structure was confirmed in the dipeptides, Ac-Ser-Asp-NHMe and Ac-Lys-Asp-NHMe with the deprotonated Asp side chain, from the dependence of the amide proton chemical shifts on temperature, solvent composition, and peptide concentration, and from the backbone dihedral angle $\phi$. The backbone conformations of these dipeptides changed with the deprotonation of Asp. In addition to the intramolecular hydrogen bond of the 4-1 type constituting $\beta$-turn structure, other kinds of intramolecular interaction between the carboxylate groups of Asp and side chains of neighboring residues were found in Ac-Ser-Asp-NHMe, Ac-Asp-Ser-NHMe, Ac-Lys-Asp-NHMe by analysis of the side chain rotamer populations, spin-lattice relaxation times, and $\mathrm{p} K_{\mathrm{a}}$ values. These side chain interactions may possibly contribute to the stabilization of the $\beta$-turn-like structure.
\end{abstract}

KEY WORDS $\beta$-Turn / Conformation / NMR / Dipeptide / Intramolecular Interaction / Aspartic Acid/

The $\beta$-turn is an important structure essential to protein folding. This turn contains at least four amino acid residues and is stabilized by a hydrogen bond of the 4-1 type involving the $\mathrm{NH}$ of $(i+3)$ th residue and $\mathrm{CO}$ of $i$ th residue. Besides the $\alpha$-helix and $\beta$-sheet structures, the $\beta$-turn structure is an important ordered structure stabilizing peptide and protein conformations. Thus, a conformational study of the $\beta$-turn structure is important for clarifying the relation between structure and function of peptides and proteins. Chou and Fasman $^{1,2}$ introduced the $\beta$-turn positional potential in their analysis of the frequency of the occurrence of each amino acid residue in various conformational protein states. This potential is defined as the possibility of the conformation of the $\beta$-turn structure for an individual amino acid residue. According to this analysis, there are two apparent features: Pro and Gly favorable to the formation of the $\beta$-turn structure, and polar residues appearing at the $\beta$-turn region.

The conformation and stability of the $\beta$-turn structure have been extensively studied by NMR (nuclear magnetic resonance), ${ }^{3,4} \mathrm{CD}$ (circular dichroism), ${ }^{5}$ IR (infra-red), ${ }^{6}$ and conformational energy calculation. ${ }^{7,8}$ Attention has been directed primarily to the Procontaining peptides in which Pro is in the $(i+1)$ th position of the $\beta$-turn structure. ${ }^{9-11}$ However, the formation of the $\beta$-turn structure has not been particularly studied for peptides containing polar amino acid residues. Among polar amino acid residues, Asp appears frequently at the corner of $\beta$-turn region. Thus in this paper, the following dipeptides containing Asp were prepared to investigate the formation of the $\beta$-turn-like structure: Ac-Asp$\mathrm{X}-\mathrm{NHMe}$, Ac-X-Asp-NHMe, and their sodium salts, in which the neighboring amino acid residues $\mathrm{X}$ were also polar, Ser, Lys, Asp, 
and Tyr. These sequences appear frequently in the $\beta$-turn region, e.g., $-\mathrm{Ser}^{86}-\mathrm{Asp}^{87}-$ and - Ser $^{100}-$ Asp $^{101}$ - in hen egg white lysozyme. ${ }^{2}$ Acetyl and $N$-methylamide groups were used as protecting groups to make the simplest peptide models capable of forming the $\beta$-turn structure. Thus, two amino acid residues are conceivably the $(i+1-i+2)$ sequence at the corner region of the structure.

It has been proposed that short range interactions contribute to the stabilization of the $\beta$-turn structure. ${ }^{12}$ As a more typical case, it is suggested that the interaction between the amino and carboxyl groups stabilizes the $\beta$ turn structure in the peptide with free terminals, ${ }^{9}$ and that the salt bridge between the side chains locks the $\beta$-turn structure. ${ }^{13}$ However, details are not available on intramolecular interaction between the $(i+1)$ th and $(i+2)$ th neighboring residues in the corner region of this structure and this interaction may play an important role in its stabilization. An analysis of the intramolecular interaction in the dipeptides was carried out to determine their effects on the formation and stabilization of this structure.

\section{EXPERIMENTAL}

All peptide samples were synthesized by the usual liquid phase method, using dicyclohexylcarbodiimide as the coupling reagent. The starting materials, Boc-Asp(OBzl)-OH, BocSer(Bzl)-OH, Boc-Lys(Z)-OH, and BocTyr(Bzl)-OH were purchased from Protein Research Foundation, Japan. The peptides containing deprotonated Asp side chains $(\operatorname{Asp}(\mathrm{Na}))$ were prepared by lyophilization of an aqueous solution of the corresponding peptides containing protonated Asp side chains following of the adjustment $\mathrm{pH}$ to 7 with $\mathrm{NaOH}$. The dipeptides prepared were identified by ${ }^{1} \mathrm{H}$ and ${ }^{13} \mathrm{C}$ NMR spectra and thin layer chromatography. ${ }^{1} \mathrm{H}$ NMR spectra were recorded on JEOL PS-100, FX-200, and FX270 spectrometers operating at 100,200 , and
$270 \mathrm{MHz}$, respectively. ${ }^{13} \mathrm{C}$ NMR spectra(25.15 $\mathrm{MHz}$ ) were recorded on a JEOL PS-100 spectrometer with complete proton decoupling. The sample temperature was $25 \pm 1^{\circ} \mathrm{C}$ and $32 \pm 1{ }^{\circ} \mathrm{C}$ for the ${ }^{1} \mathrm{H}$ and ${ }^{13} \mathrm{C}$ measurements, respectively. The chemical shifts was reported relative to tetramethylsilane unless otherwise noted. ${ }^{1} \mathrm{H}$ and ${ }^{13} \mathrm{C}$ assignments were achieved by comparison with literature values. ${ }^{14-16}$ Selective homo-spin decoupling was also used for the assignment of the ${ }^{1} \mathrm{H}$ spectra. The resonances of two $\beta$-protons were assigned using customary method. ${ }^{17,18}{ }^{1} \mathrm{H}$ resonances of the ABX spin system $\mathrm{C}^{\alpha} \mathrm{HC}^{\beta} \mathrm{H}_{2}$ were analyzed using a simulation and iteration program, LAOCON. ${ }^{13} \mathrm{C}$ spin-lattice relaxation times $\left(T_{1}\right)$ were measured by the inversion recovery method. ${ }^{2} \mathrm{H}_{2} \mathrm{O}$ and perdeuterated dimethyl sulphoxide (DMSO- $\left.d_{6}\right)$ were used as solvents. The vicinal coupling constants ${ }^{3} J\left(\mathrm{HNC}^{\alpha} \mathrm{H}\right)$ were measured in a mixed solvent of $90 \%$ $\mathrm{H}_{2} \mathrm{O} / 10 \%{ }^{2} \mathrm{H}_{2} \mathrm{O}$. The concentration of the sample solution was 0.03 and $0.2 \mathrm{M}$ for ${ }^{1} \mathrm{H}$ and ${ }^{13} \mathrm{C}$ NMR measurements, respectively. The $\mathrm{p}^{2} \mathrm{H}$ values of the NMR samples were adjusted with ${ }^{2} \mathrm{HCl}$ and $\mathrm{NaO}^{2} \mathrm{H}$. No correction was made for $\mathrm{pH}$ and $\mathrm{p}^{2} \mathrm{H}$. All deuterated reagents were purchased from Merck Sharp and Dohme Canada Ltd.

\section{RESULTS AND DISCUSSION}

\section{Formation of the $\beta$-Turn-Like Structure}

Most of the $\beta$-turn structures have 4-1 hydrogen bonds forming ten-membered rings (so-called $\mathrm{C}_{10}$ structure). If the protected dipeptide forms a $\beta$-turn structure, a hydrogen bond is formed between the amide proton of a $N$-methylamide group and the carbonyl group of an acetyl group. Here, the $N$ methylamide and acetyl groups are included in the $\mathrm{C}$ - and $\mathrm{N}$-terminal protecting groups, respectively.

Temperature coefficients of the amide proton chemical shifts are useful for detecting intramolecular hydrogen bonding. ${ }^{19}$ The 
chemical shifts of intramolecularly hydrogen bonded amide protons of peptides showed less substantial temperature dependence than those of protons exposed to the solvent. When the chemical shift change $(\mathrm{d} \delta$ ) depends linearly on the temperature change $(\mathrm{d} T)$, the forms of hydrogen bonding are classified on the basis of the magnitude of $\mathrm{d} \delta / \mathrm{d} T$. If $\mathrm{d} \delta / \mathrm{d} T$ is in the range from 0 to $-3 \times 10^{-3} \mathrm{ppm} \mathrm{deg}{ }^{-1}$, intramolecular hydrogen bonding is quite probable, but if $\mathrm{d} \delta / \mathrm{d} T$ is $-6 \times 10^{-3}$ to $-10 \times$ $10^{-3} \mathrm{ppm} \mathrm{deg}{ }^{-1}$, hydrogen bonding interaction occurs mainly between the solute and solvent.

Table I shows the temperature coefficients of the chemical shifts of the amide protons measured from 25 to $65^{\circ} \mathrm{C}$ in DMSO- $d_{6}$ solutions. The values $\mathrm{d} \delta / \mathrm{d} T$ were smaller than $-3 \times 10^{-3}$ ppm deg ${ }^{-1}$ for all amide protons in Ac-Asp$\mathrm{X}-\mathrm{NHMe}$ and Ac-X-Asp-NHMe. This suggests the absence of any particular intramolecular hydrogen bonding in the dipeptides whose Asp side chains are protonated. Small but anomalous positive temperature coefficients were observed for the amide protons of $\mathrm{N}$-methylamide group in $\mathrm{Ac}-\mathrm{X}-\mathrm{Asp}(\mathrm{Na})$
NHMe except for Ac-Asp(Na)-Asp(Na)NHMe. These results may be due to hydrogen bonding and/or charge effect ${ }^{20}$ from the deprotonated Asp side chains. If hydrogen bonds are responsible for the temperature coefficients,

Table I. Temperature coefficients of amide proton chemical shifts in DMSO- $d_{6}$ solution

\begin{tabular}{|c|c|c|c|}
\hline \multirow{3}{*}{ Compound } & \multicolumn{3}{|c|}{$\mathrm{d} \delta / \mathrm{d} T$} \\
\hline & \multicolumn{3}{|c|}{$10^{3} \mathrm{ppm} \mathrm{deg}^{-1}$} \\
\hline & Asp $\mathrm{N} \underline{H}$ & I $\mathrm{XN} \underline{\mathrm{H}}$ & $\mathrm{N} \underline{\mathrm{H}} \mathrm{Me}$ \\
\hline Ac-Asp-Ser-NHMe & -4.49 & -4.81 & -4.18 \\
\hline $\mathrm{Ac}-\mathrm{Asp}(\mathrm{Na})-\mathrm{Ser}-\mathrm{NHMe}$ & -4.38 & -6.96 & -4.13 \\
\hline Ac-Ser-Asp-NHMe & -5.68 & -6.00 & -3.63 \\
\hline Ac-Ser-Asp(Na)-NHMe & -2.80 & -16.0 & +3.26 \\
\hline Ac-Asp-Tyr-NHMe & -4.44 & -5.47 & -5.47 \\
\hline $\operatorname{Ac}-\operatorname{Asp}(\mathrm{Na})-\mathrm{Tyr}-\mathrm{NHMe}$ & -2.75 & -4.03 & -5.89 \\
\hline Ac-Tyr-Asp-NHMe & -5.32 & -5.62 & -3.92 \\
\hline Ac-Tyr-Asp(Na)-NHMe & -4.99 & -7.84 & +2.03 \\
\hline Ac-Lys-Asp $(\mathrm{Na})-\mathrm{NHMe}$ & -7.12 & -7.12 & +3.11 \\
\hline Ac-Asp-Asp-NHMe & $-5.09^{\mathrm{a}}$ & $-4.86^{\mathrm{b}}$ & -3.75 \\
\hline $\mathrm{Ac}-\mathrm{Asp}(\mathrm{Na})-\mathrm{Asp}(\mathrm{Na})-\mathrm{NHMe}$ & n.d..$^{\mathrm{a}, \mathrm{c}}$ & $-4.65^{b}$ & -4.65 \\
\hline
\end{tabular}

a $\mathrm{N}$-terminal residue.

b C-terminal residue.

c Not determined due to non-linearity.
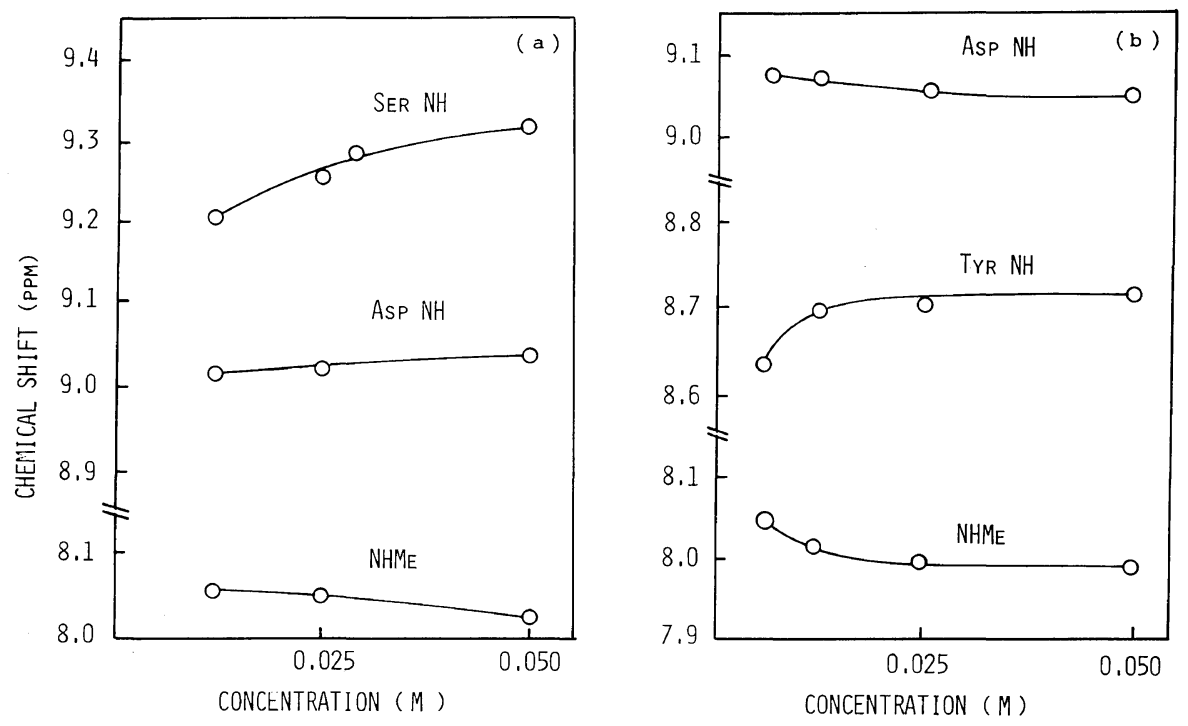

Figure 1. Concentration dependence of amide proton chemical shifts in DMSO- $d_{6}$. (a) Ac-SerAsp(Na)-NHMe; (b) Ac-Tyr-Asp(Na)-NHMe. 
there are three possible hydrogen bondings. The first is an intermolecular one between peptides, and is less important in DMSO- $d_{6}$ solution. In fact, the $N$-methylamide proton resonances do not indicate significant concentration dependent shifts as shown in Figure 1. The other two are intramolecular; one forming a $\mathrm{C}_{10}$ structure as was found in the $\beta$ turn structure whose amide proton was hydrogen bonded to an acetyl carbonyl group, and the other, forming a seven-membered ring with the amide proton hydrogen bonded to the Asp side chain carboxylate group. In the latter case, the chemical shifts of the amide protons may be influenced by the charge of Asp side chains.

The dependence of the amide proton chemical shifts on the solvent composition was measured so as to make a distinction between the two types of intramolecular hydrogen bonding. ${ }^{21}$ The results are shown in Figure 2 for Ac-Ser-Asp-NHMe and Ac-Tyr-Asp$\mathrm{NHMe}$, and their sodium salts. Here, the solvent composition was varied from pure DMSO- $d_{6}$ to $40: 60(\mathrm{v} / \mathrm{v})$ DMSO- $d_{6} / \mathrm{C}^{2} \mathrm{HCl}_{3}$ at a constant peptide concentration. In this range, no change was observed in the coupling constant ${ }^{3} J\left(\mathrm{HNC}^{\alpha} \mathrm{H}\right)$, indicating no change in the backbone conformation. Since DMSO- $d_{6}$ is a good hydrogen acceptor solvent and $\mathrm{C}^{2} \mathrm{HCl}_{3}$ has less hydrogen bonding ability, upfield shifts are expected for solvent-exposed amide protons with an increase in $\mathrm{C}^{2} \mathrm{HCl}_{3}$ content. The chemical shifts of intramolecularly hydrogen bonded amide protons are less affected by the change on solvent composition. The amide protons of Asp and Ser of both protonated and deprotonated forms of Ac-Ser-Asp-NHMe showed upfield shifts with increasing $\mathrm{C}^{2} \mathrm{HCl}_{3}$ content. The amide proton of $\mathrm{N}$-methylamide group of Ac-Ser-AspNHMe showed a large upfield shift, while a small lowfield shift was observed for the deprotonated form Ac-Ser-Asp(Na)-NHMe. For all amide protons except for Asp amide proton of Ac-Tyr-Asp(Na)-NHMe, large up- field shifts were observed not only in the protonated but also in the deprotonated AcTyr-Asp-NHMe. It is unlikely that the amide proton of $N$-methylamide group of Ac-Tyr$\operatorname{Asp}(\mathrm{Na})-\mathrm{NHMe}$ participates in a strong intramolecular hydrogen bond. Thus, the anomalous positive temperature coefficient of the amide proton is due to the charge effect of the deprotonated Asp side chain, which may be close to the amide proton. From these results, it may be concluded that hydrogen bonds were the type of $\mathrm{C}_{10}$ structure for Ac-Ser-Asp(Na) $\mathrm{NHMe}$ and that of seven-membered ring for Ac-Tyr-Asp(Na)-NHMe.

The dependence of amide proton chemical shifts on solvent composition could not be observed for Ac-Lys-Asp(Na)-NHMe and Ac-Asp(Na)-Asp(Na)-NHMe, because of poor solubility in DMSO- $d_{6}-\mathrm{C}^{2} \mathrm{HCl}_{3}$ mixture. As suggested by the value of the backbone dihedral angle $\phi$, the anomalous positive temperature coefficient of the amide proton of the $\mathrm{N}$-methylamide group in Ac-Lys-Asp( $\mathrm{Na}$ ) NHMe may be related to hydrogen bonding which induces a change in the overall backbone conformation.

\section{Backbone Conformation of Dipeptides}

Tables II and III show the vicinal coupling constant ${ }^{3} J\left(\mathrm{HNC}^{\alpha} \mathrm{H}\right)$ and dihedral angle $\phi$ obtained using the Karplus-type relationship of Demarco et al. ${ }^{22}$ Although one coupling constant yields from two to four dihedral angles, the probable one can be selected from the Ramachandran plot, ${ }^{23}$ since the dipeptides are not sterically constrained. According to this plot, most of the amino acid residues take on a $\phi$ value around $-90^{\circ}$. Values of about $-90^{\circ}$ should be used.

In the $\beta$-turn structure, the $\phi$ value of the $(i+2)$ th residue depends on the type of turn, while that of $(i+1)$ th residue is about $-60^{\circ}$ for almost any $\beta$-turn structure, i.e., types I, II or III. ${ }^{2}$ In solution, the $\phi$ values were observed as a time average of those for possible conformations. Though some of the changes in $\phi$ 
Conformation of Aspartic Acid-Containing Dipeptides
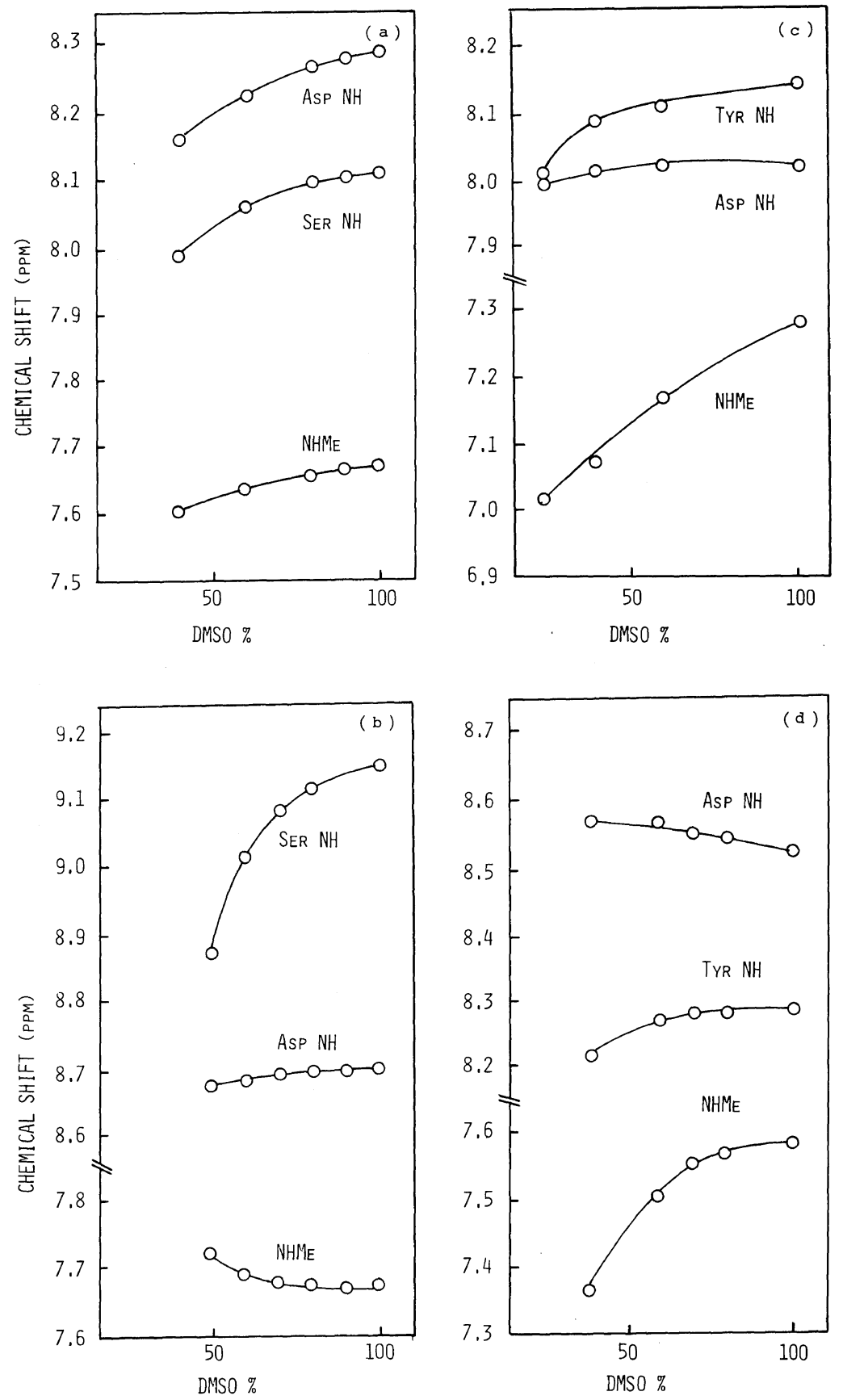

Figure 2. Solvent composition dependence of amide proton chemical shifts in DMSO- $d_{6} / \mathrm{C}^{2} \mathrm{HCl}_{3}$ mixture. (a) Ac-Ser-Asp-NHMe; (b) Ac-Ser-Asp(Na)-NHMe; (c) Ac-Tyr-Asp-NHMe; (d) Ac-TyrAsp(Na)-NHMe. 
Table II. Values for the dihedral angle $\phi$ for dipeptides in DMSO- $d_{6}$ solution

\begin{tabular}{|c|c|c|c|}
\hline \multirow{2}{*}{ Compound } & \multirow{2}{*}{ Residue } & \multirow{2}{*}{$\frac{{ }^{3} J\left(\mathrm{HNC}^{\alpha} \mathrm{H}\right)}{\mathrm{Hz}}$} & \multirow{2}{*}{$\frac{\phi}{c}$} \\
\hline & & & \\
\hline \multirow[t]{2}{*}{ Ac-Asp-Ser-NHMe } & Asp & $7.8_{1}$ & $-96 \pm 8,-144 \pm 8$ \\
\hline & Ser & $7.8_{1}$ & $-96 \pm 8,-144 \pm 8$ \\
\hline \multirow[t]{2}{*}{ Ac-Asp(Na)-Ser-NHMe } & Asp & $7.3_{2}$ & $-90 \pm 7,-150 \pm 7$ \\
\hline & Ser & $6.3_{5}$ & $-80 \pm 6,-160 \pm 6$ \\
\hline \multirow[t]{2}{*}{ Ac-Ser-Asp-NHMe } & Asp & $8.3_{0}$ & $-103 \pm 9,-137 \pm 9$ \\
\hline & Ser & $7.3_{2}$ & $-90 \pm 7,-150 \pm 7$ \\
\hline \multirow[t]{2}{*}{$\mathrm{Ac}-\mathrm{Ser}-\mathrm{Asp}(\mathrm{Na})-\mathrm{NHMe}$} & Asp & $8.4_{0}$ & $-104 \pm 9,-136 \pm 9$ \\
\hline & Ser & $5.8_{6}$ & $\begin{array}{l}+42 \pm 7, \quad+78 \pm 7 \\
-76 \pm 5, \quad-164 \pm 5\end{array}$ \\
\hline \multirow[t]{2}{*}{ Ac-Asp-Tyr-NHMe } & Asp & $7.8_{2}$ & $-96 \pm 8,-144 \pm 8$ \\
\hline & Tyr & $8.3_{0}$ & $-103 \pm 9,-137 \pm 9$ \\
\hline \multirow[t]{2}{*}{ Ac-Asp(Na)-Tyr-NHMe } & Asp & $7.8_{2}$ & $-96 \pm 8,-144 \pm 8$ \\
\hline & Tyr & $8.3_{0}$ & $-103 \pm 9,-137 \pm 9$ \\
\hline \multirow[t]{2}{*}{ Ac-Tyr-Asp-NHMe } & Asp & $7.3_{2}$ & $-90 \pm 7,-150 \pm 7$ \\
\hline & Tyr & $7.8_{1}$ & $-96 \pm 8,-144 \pm 8$ \\
\hline \multirow[t]{2}{*}{ Ac-Tyr-Asp(Na)-NHMe } & Asp & $6.8_{4}$ & $-85 \pm 6,-155 \pm 6$ \\
\hline & Tyr & $7.8_{1}$ & $-96 \pm 8,-144 \pm 8$ \\
\hline \multirow[t]{2}{*}{ Ac-Lys-Asp(Na)-NHMe } & Asp & $6.3_{5}$ & $-80 \pm 6,-160 \pm 6$ \\
\hline & Lys & $6.3_{5}$ & $-80 \pm 6,-160 \pm 6$ \\
\hline \multirow[t]{2}{*}{ Ac-Asp-Asp-NHMe } & $\mathrm{Asp}^{\mathrm{a}}$ & $7.8_{1}$ & $-96 \pm 8,-144 \pm 8$ \\
\hline & $A s p^{b}$ & $7.3_{2}$ & $-90 \pm 7,-150 \pm 7$ \\
\hline \multirow[t]{2}{*}{$\mathrm{Ac}-\mathrm{Asp}(\mathrm{Na})-\mathrm{Asp}(\mathrm{Na})-\mathrm{NHMe}$} & $\mathrm{Asp}^{\mathrm{a}}$ & $7.3_{3}$ & $-90 \pm 7,-150 \pm 7$ \\
\hline & $A s p^{b}$ & $7.8_{1}$ & $-96 \pm 8,-144 \pm 8$ \\
\hline
\end{tabular}

a $\mathrm{N}$-terminal residue.

b C-terminal residue.

values are small compared to estimated error, change in $\phi$ values may reflect changes in the population of prefered conformations.

As shown in Table II, in DMSO- $d_{6}$, the $\phi$ values depend on the ionic state of Asp side chains. The $\phi$ values of $\mathrm{N}$-terminal residues corresponding to the $(i+1)$ th residue of the $\beta$ turn sequence become closer to $-60^{\circ}$ on the deprotonation of Asp in Ac-Ser-Asp-NHMe and Ac-Asp-Asp-NHMe. Thus, in these peptides on deprotonation of Asp, conformational change may be induced more suitably for the formation of the $\beta$-turn-like structure. AcAsp-Tyr-NHMe and Ac-Tyr-Asp-NHMe have the same values as those of corresponding sodium salts, except for Asp in the latter peptide, possibly because of the formation of the seven-membered ring. The ionic state of the Asp side chain affects the overall backbone conformation of Ac-Asp-Ser-NHMe, AcSer-Asp-NHMe, Ac-Asp-Asp-NHMe, and Ac-Tyr-Asp-NHMe. Because of the poor solubility, $\phi$ values could not be obtained for the peptide containing Lys except for AcLys-Asp(Na)-NHMe. The $\phi$ value of AcLys-Asp(Na)-NHMe is also suitable for the formation of the $\beta$-turn-like structure.

In the mixed solvent, $\mathrm{H}_{2} \mathrm{O}^{2}{ }^{2} \mathrm{H}_{2} \mathrm{O}$ 90:10 $(\mathrm{v} / \mathrm{v})$, the $\phi$ values are not the same as those indicated in Table III; for certain peptides, a similar tendency was observed for the change in $\phi$ values on increasing the $\mathrm{pH}$ from 2.5 to 4.0.

From the $\phi$ values and evidence for the occurrence of intramolecular hydrogen bonds, we conclude that formation of the $\beta$-turn-like structure takes place most prabably in AcSer-Asp-NHMe and Ac-Lys-Asp-NHMe as 
Table III. Values for the dihedral angle $\phi$ for dipeptides in aqueous solution ${ }^{\mathrm{a}}$

\begin{tabular}{|c|c|c|c|c|}
\hline \multirow{2}{*}{ Compound } & \multirow{2}{*}{$\mathrm{pH}^{\mathrm{b}}$} & \multirow{2}{*}{ Residue } & \multirow{2}{*}{$\frac{{ }^{3} J\left(\mathrm{HNC}^{\alpha} \mathrm{H}\right)}{\mathrm{Hz}}$} & $\phi$ \\
\hline & & & & $\circ$ \\
\hline \multirow[t]{4}{*}{ Ac-Asp-Ser-NHMe } & 2.5 & Asp & $7.3_{2}$ & $-90 \pm 7,-150 \pm 7$ \\
\hline & & Ser & $6.8_{3}$ & $-84 \pm 6,-156 \pm 6$ \\
\hline & 4.0 & Asp & $6.9_{4}$ & $-86 \pm 6,-154 \pm 6$ \\
\hline & & Ser & $6.9_{4}^{4}$ & $-86 \pm 6,-154 \pm 6$ \\
\hline \multirow[t]{4}{*}{ Ac-Ser-Asp-NHMe } & 2.5 & Asp & $7.8_{1}$ & $-96 \pm 8,-144 \pm 8$ \\
\hline & & Ser & $6.3_{4}$ & $-79 \pm 6,-161 \pm 6$ \\
\hline & 4.0 & Asp & $7.5_{8}$ & $-92 \pm 7,-148 \pm 7$ \\
\hline & & Ser & $6.9_{2}$ & $-85 \pm 6,-155 \pm 6$ \\
\hline \multirow[t]{4}{*}{ Ac-Asp-Tyr-NHMe } & 2.5 & Asp & $8.2_{4}$ & $-101 \pm 9,-139 \pm 9$ \\
\hline & & Tyr & $7.5_{8}$ & $-92 \pm 7,-148 \pm 7$ \\
\hline & 4.0 & Asp & $7.9_{1}$ & $-96 \pm 8,-144 \pm 8$ \\
\hline & & Tyr & $6.5_{9}$ & $-82 \pm 6,-158 \pm 6$ \\
\hline \multirow[t]{4}{*}{ Ac-Tyr-Asp-NHMe } & 2.5 & Asp & $8.2_{4}$ & $-101 \pm 9,-139 \pm 9$ \\
\hline & & Tyr & $6.2_{6}$ & $\begin{array}{l}+55 \pm 7, \quad+65 \pm 7 \\
-79 \pm 6, \quad-161 \pm 6\end{array}$ \\
\hline & 4.0 & Asp & $7.2_{5}$ & $-89 \pm 7,-151 \pm 7$ \\
\hline & & Tyr & 6.93 & $-85 \pm 6,-155 \pm 6$ \\
\hline \multirow[t]{4}{*}{ Ac-Asp-Lys-NHMe } & 2.5 & Asp & $7.2_{5}$ & $-89 \pm 7,-151 \pm 7$ \\
\hline & & Lys & $6.5_{9}$ & $-82 \pm 6,-158 \pm 6$ \\
\hline & 4.0 & Asp & $6.7_{5}$ & $-84 \pm 6,-156 \pm 6$ \\
\hline & & Lys & $6.5_{9}$ & $-82 \pm 6,-158 \pm 6$ \\
\hline \multirow[t]{4}{*}{ Ac-Lys-Asp-NHMe } & 2.5 & Asp & $7.9_{9}$ & $-97 \pm 8,-143 \pm 8$ \\
\hline & & Lys & $5.6_{1}$ & $\begin{array}{l}+38 \pm 8, \quad+82 \pm 8 \\
-73 \pm 5, \quad-167 \pm 5\end{array}$ \\
\hline & 4.0 & Asp & $6.9_{2}$ & $-85 \pm 6,-155 \pm 6$ \\
\hline & & Lys & $6.5_{9}$ & $-82 \pm 6,-158 \pm 6$ \\
\hline \multirow[t]{4}{*}{ Ac-Asp-Asp-NHMe } & 2.5 & $A s p^{c}$ & $7.2_{5}$ & $-89 \pm 7,-151 \pm 7$ \\
\hline & & $\mathrm{Asp}^{\mathrm{d}}$ & $8.2_{4}$ & $-101 \pm 9,-139 \pm 9$ \\
\hline & 4.0 & $A s p^{c}$ & $6.5_{9}$ & $-82 \pm 6,-158 \pm 6$ \\
\hline & & $\mathrm{Asp}^{\mathrm{d}}$ & 7.25 & $-89 \pm 7,-151 \pm 7$ \\
\hline
\end{tabular}

a Coupling constants ${ }^{3} J\left(\mathrm{HNC}^{\alpha} \mathrm{H}\right)$ were measured in a mixed solvent of $\mathrm{H}_{2} \mathrm{O}^{2} \mathrm{H}_{2} \mathrm{O} 90: 10(\mathrm{v} / \mathrm{v})$.

b $\mathrm{pH}$ meter readings.

c $\mathrm{N}$-terminal residue.

d C-terminal residue.

the time average conformation in solution. Further, it may be said that the deprotonation of Asp is necessary for the preferential formation of the $\beta$-turn-like structure.

\section{Side Chain Rotamer Population}

Side chain conformations were determined by spin analysis of $\alpha$ and $\beta$ proton resonances so as to investigate further the formation of the $\beta$-turn-like structure. If the dipeptide backbone takes on a folded conformation such as that of the $\beta$-turn structure, the side chains can approach each other. In the dipeptide with a $\beta$ turn-like structure, both side chains become mutually close enough to interact when the $\mathrm{N}$ terminal and C-terminal residues take $(t)$ - and $\left(g^{-}\right)$-rotamers, respectively, or both take $\left(g^{+}\right)$rotamers. Thus, the rotamer population is expected to reflect the backbone conformation and (side chain)-(side chain) interactions. Much attention was directed to the rotamer population $P_{g^{+}}$, since the amino acid residue does not favorably take the $\left(g^{+}\right)$-rotamer except for Ser in protein. ${ }^{24}$ The rotamers about 


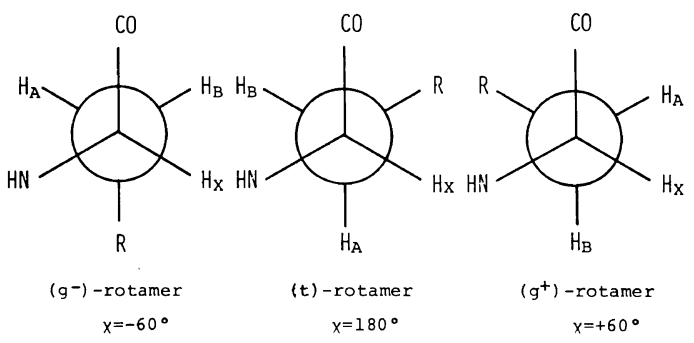

Figure 3. Three stable rotamers about the $C^{\alpha}-C^{\beta}$ bond and their notations.

the $\mathrm{C}^{\alpha}-\mathrm{C}^{\beta}$ bond and their notations are shown in Figure 3.

In Table IV are listed the values for the vicinal coupling constant ${ }^{3} J\left(\mathrm{HC}^{\alpha} \mathrm{C}^{\beta} \mathrm{H}\right)$ and rotamer populations for the dipeptides and Ac-Asp-NHMe at $\mathrm{p}^{2} \mathrm{H}$ 3, 7, and 13. The population were calculated using the approximations of Pachler ${ }^{25}$ and Feeney ${ }^{26}$ (shown in parentheses). The side chain of Asp was fully protonated and deprotonated at $\mathrm{p}^{2} \mathrm{H} 3$ and 7 , respectively.

Table IV indicates that the rotamer populations of both residues change in a complicated manner with change in the ionization state of the side chains in Ac-Asp-Ser-NHMe. With an increase in $\mathrm{p}^{2} \mathrm{H}$ from 3 to $7, P_{g^{+}}$increases for both residues, especially Asp. In the monomer model, Ac-Asp-NHMe, the $P_{g^{+}}$dose not increase on deprotonation, due to repulsive interaction between the side chain carboxylate and backbone carbonyl groups. Thus, the large increase in $P_{g^{+}}$for Asp in the dipeptide may be induced by side chain interactions with Ser. This indicates the formation of hydrogen bonds between the side chain carboxylate and hydroxyl groups. The occurrence of such an interaction is supported by the titration behavior of proton chemical shifts, as shown in Figure 4. The deprotonation of Asp caused larger shifts of the Ser $\beta$ proton than $\alpha$ proton. As the $\mathrm{p}^{2} \mathrm{H}$ increased from 7 to 13 , the value of $P_{g^{+}}$decreased, becoming almost the same as that at $\mathrm{p}^{2} \mathrm{H} 3$ for either residue in Ac-Asp-SerNHMe. This suggests that hydrogen bonds
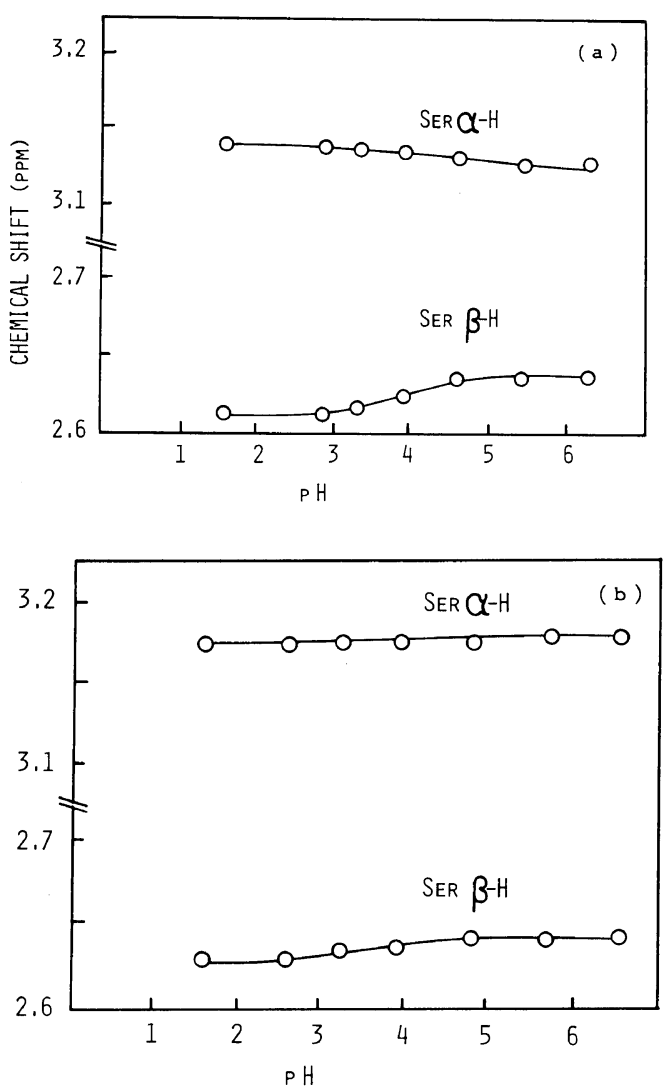

Figure 4. $\mathrm{pH}$ titration shifts of $\alpha$ and $\beta$ protons of Ser. (a) Ac-Asp-Ser-NHMe; (b) Ac-Ser-Asp-NHMe. The chemical shift for $\beta$ proton is averaged value of two $\beta$ protons. The internal reference for the chemical shifts was tert-BuOH.

are broken by repulsive force between the charged side chains. The change in $P_{g^{+}}$for Asp cannot be explained without taking the (side chain)-(side chain) interaction into consideration. Although no intramolecular hydrogen bonded $\mathrm{C}_{10}$ structure could be found, folded conformations are likely to occur at $\mathrm{p}^{2} \mathrm{H} 7$ in Ac-Asp-Ser-NHMe.

A similar tendency was observed for side chain rotamer populations in Ac-Ser-AspNHMe, although the change in $P_{g_{+}}$was small compared to the experimental error. Thus, the preferred conformation is a folded one, which is quite consistent with the formation of $\mathrm{C}_{10}$ structure found in DMSO- $d_{6}$ solution. 
Conformation of Aspartic Acid-Containing Dipeptides

Table IV. Proton coupling constants $(\mathrm{Hz})$ and rotamer populations $\mathrm{s}^{\mathrm{a}}$ of dipeptides in aqueous solution

\begin{tabular}{|c|c|c|c|c|c|c|c|c|}
\hline Compound & $\mathrm{p}^{2} \mathrm{H}$ & Residue & ${ }^{3} J_{\mathrm{AX}}$ & ${ }^{3} J_{\mathrm{BX}}$ & ${ }^{2} J_{\mathrm{AB}}$ & $P_{g^{-}}$ & $P_{t}$ & $P_{g^{+}}$ \\
\hline \multirow[t]{6}{*}{ Ac-Asp-Ser-NHMe } & 3 & Asp & $7.2_{9}$ & $5.9_{4}$ & $16.7_{9}$ & $\begin{array}{c}0.44 \\
(0.45)\end{array}$ & $\begin{array}{c}0.30 \\
(0.33)\end{array}$ & $\begin{array}{c}0.26 \\
(0.22)\end{array}$ \\
\hline & & Ser & $4.6_{1}$ & $5.2_{8}$ & $11.8_{7}$ & $\begin{array}{c}0.18 \\
(0.17)\end{array}$ & $\begin{array}{c}0.24 \\
(0.14)\end{array}$ & $\begin{array}{c}0.58 \\
(0.69)\end{array}$ \\
\hline & 7 & Asp & $6.0_{4}$ & $5.6_{2}$ & $15.0_{9}$ & $\begin{array}{c}0.31 \\
(0.32)\end{array}$ & $\begin{array}{c}0.24 \\
(0.24)\end{array}$ & $\begin{array}{c}0.45 \\
(0.44)\end{array}$ \\
\hline & & Ser & $4.8_{7}$ & $4.4_{7}$ & $11.5_{7}$ & $\begin{array}{c}0.20 \\
(0.22)\end{array}$ & $\begin{array}{c}0.17 \\
(0.05)\end{array}$ & $\begin{array}{c}0.63 \\
(0.73)\end{array}$ \\
\hline & 13 & Asp & $7.1_{5}$ & $6.3_{5}$ & $17.7_{4}$ & $\begin{array}{c}0.41 \\
(0.42)\end{array}$ & $\begin{array}{c}0.34 \\
(0.38)\end{array}$ & $\begin{array}{c}0.25 \\
(0.20)\end{array}$ \\
\hline & & Ser & $4.5_{2}$ & $5.1_{5}$ & $12.1_{6}$ & $\begin{array}{c}0.17 \\
(0.17)\end{array}$ & $\begin{array}{c}0.23 \\
(0.13)\end{array}$ & $\begin{array}{c}0.60 \\
(0.70)\end{array}$ \\
\hline \multirow[t]{6}{*}{ Ac-Ser-Asp-NHMe } & 3 & Asp & $7.4_{1}$ & $5.7_{7}$ & $16.9_{7}$ & $\begin{array}{c}0.44 \\
(0.47)\end{array}$ & $\begin{array}{c}0.29 \\
(0.32)\end{array}$ & $\begin{array}{c}0.27 \\
(0.21)\end{array}$ \\
\hline & & Ser & $5.2_{7}$ & $5.9_{4}$ & $11.5_{4}$ & $\begin{array}{c}0.24 \\
(0.23)\end{array}$ & $\begin{array}{c}0.30 \\
(0.25)\end{array}$ & $\begin{array}{c}0.46 \\
(0.52)\end{array}$ \\
\hline & 7 & Asp & $6.8_{4}$ & $5.6_{2}$ & $16.1_{2}$ & $\begin{array}{c}0.39 \\
(0.40)\end{array}$ & $\begin{array}{c}0.28 \\
(0.28)\end{array}$ & $\begin{array}{c}0.33 \\
(0.32)\end{array}$ \\
\hline & & Ser & $5.3_{8}$ & $5.3_{7}$ & $11.7_{2}$ & $\begin{array}{c}0.25 \\
(0.25)\end{array}$ & $\begin{array}{c}0.25 \\
(0.19)\end{array}$ & $\begin{array}{c}0.50 \\
(0.56)\end{array}$ \\
\hline & 13 & Asp & $7.0_{8}$ & $6.8_{4}$ & $15.3_{8}$ & $\begin{array}{c}0.41 \\
(0.41)\end{array}$ & $\begin{array}{c}0.39 \\
(0.44)\end{array}$ & $\begin{array}{c}0.20 \\
(0.15)\end{array}$ \\
\hline & & Ser & $4.9_{4}$ & $5.6_{1}$ & $11.2_{1}$ & $\begin{array}{c}0.21 \\
(0.20)\end{array}$ & $\begin{array}{c}0.27 \\
(0.20)\end{array}$ & $\begin{array}{c}0.52 \\
(0.60)\end{array}$ \\
\hline \multirow[t]{6}{*}{ Ac-Asp-Tyr-NHMe } & 3 & Asp & $7.8_{5}$ & $5.6_{4}$ & $16.0_{9}$ & $\begin{array}{c}0.48 \\
(0.52)\end{array}$ & $\begin{array}{c}0.28 \\
(0.32)\end{array}$ & $\begin{array}{c}0.24 \\
(0.16)\end{array}$ \\
\hline & & Tyr & $8.1_{1}$ & $6.2_{0}$ & $14.3_{0}$ & $\begin{array}{c}0.50 \\
(0.53)\end{array}$ & $\begin{array}{c}0.33 \\
(0.40)\end{array}$ & $\begin{array}{c}0.17 \\
(0.07)\end{array}$ \\
\hline & 7 & Asp & $8.0_{6}$ & $6.3_{5}$ & $15.8_{7}$ & $\begin{array}{c}0.50 \\
(0.53)\end{array}$ & $\begin{array}{c}0.34 \\
(0.40)\end{array}$ & $\begin{array}{c}0.16 \\
(0.07)\end{array}$ \\
\hline & & Tyr & $8.3_{0}$ & $6.1_{1}$ & $14.1_{6}$ & $\begin{array}{c}0.52 \\
(0.55)\end{array}$ & $\begin{array}{c}0.32 \\
(0.39)\end{array}$ & $\begin{array}{c}0.16 \\
(0.06)\end{array}$ \\
\hline & 13 & Asp & $8.3_{0}$ & $5.8_{6}$ & $16.1_{1}$ & $\begin{array}{c}0.52 \\
(0.56)\end{array}$ & $\begin{array}{c}0.30 \\
(0.36)\end{array}$ & $\begin{array}{c}0.18 \\
(0.08)\end{array}$ \\
\hline & & Tyr & $7.5_{7}$ & $6.8_{3}$ & $14.2_{9}$ & $\begin{array}{c}0.45 \\
(0.46)\end{array}$ & $\begin{array}{c}0.39 \\
(0.44)\end{array}$ & $\begin{array}{c}0.16 \\
(0.10)\end{array}$ \\
\hline \multirow[t]{6}{*}{ Ac-Tyr-Asp-NHMe } & 3 & Asp & $6.8_{4}$ & $6.2_{6}$ & $16.9_{8}$ & $\begin{array}{c}0.39 \\
(0.40)\end{array}$ & $\begin{array}{c}0.33 \\
(0.36)\end{array}$ & $\begin{array}{c}0.28 \\
(0.24)\end{array}$ \\
\hline & & Tyr & $7.2_{5}$ & $7.2_{4}$ & $13.5_{1}$ & $\begin{array}{c}0.42 \\
(0.42)\end{array}$ & $\begin{array}{c}0.42 \\
(0.50)\end{array}$ & $\begin{array}{c}0.16 \\
(0.08)\end{array}$ \\
\hline & 7 & Asp & \multicolumn{2}{|c|}{$6.2_{4}$} & - & - & - & - \\
\hline & & Tyr & $7.5_{5}$ & $6.6_{5}$ & $13.4_{3}$ & $\begin{array}{c}0.45 \\
(0.47)\end{array}$ & $\begin{array}{c}0.37 \\
(0.44)\end{array}$ & $\begin{array}{c}0.18 \\
(0.09)\end{array}$ \\
\hline & 13 & Asp & \multicolumn{2}{|c|}{$5.9_{4}$} & - & - & - & - \\
\hline & & Tyr & $7.5_{7}$ & $7.3_{2}$ & $13.9_{1}$ & $\begin{array}{c}0.45 \\
(0.46)\end{array}$ & $\begin{array}{c}0.43 \\
(0.50)\end{array}$ & $\begin{array}{c}0.12 \\
(0.04)\end{array}$ \\
\hline
\end{tabular}


Table IV. (continued)

\begin{tabular}{|c|c|c|c|c|c|c|c|c|}
\hline Compound & $\mathrm{p}^{2} \mathrm{H}$ & Residue & ${ }^{3} J_{\mathrm{AX}}$ & ${ }^{3} J_{\mathrm{BX}}$ & ${ }^{2} J_{\mathrm{AB}}$ & $P_{g^{-}}$ & $P_{t}$ & $P_{g^{+}}$ \\
\hline \multirow[t]{3}{*}{ Ac-Asp-Lys-NHMe } & 3 & Asp & $7.2_{5}$ & $6.7_{0}$ & $17.1_{4}$ & $\begin{array}{c}0.42 \\
(0.43)\end{array}$ & $\begin{array}{c}0.37 \\
(0.43)\end{array}$ & $\begin{array}{c}0.22 \\
(0.14)\end{array}$ \\
\hline & 7 & Asp & $7.3_{3}$ & $6.8_{3}$ & $15.0_{0}$ & $\begin{array}{c}0.43 \\
(0.44)\end{array}$ & $\begin{array}{c}0.39 \\
(0.45)\end{array}$ & $\begin{array}{c}0.18 \\
(0.11)\end{array}$ \\
\hline & 13 & Asp & $7.5_{5}$ & $6.8_{3}$ & - & $\begin{array}{c}0.45 \\
(0.46)\end{array}$ & $\begin{array}{c}0.39 \\
(0.46)\end{array}$ & $\begin{array}{c}0.16 \\
(0.08)\end{array}$ \\
\hline \multirow[t]{3}{*}{ Ac-Lys-Asp-NHMe } & 3 & Asp & $8.2_{4}$ & $5.6_{1}$ & $16.8_{1}$ & $\begin{array}{c}0.51 \\
(0.56)\end{array}$ & $\begin{array}{c}0.27 \\
(0.32)\end{array}$ & $\begin{array}{c}0.22 \\
(0.12)\end{array}$ \\
\hline & 7 & Asp & $7.3_{3}$ & $5.6_{2}$ & $15.6_{3}$ & $\begin{array}{c}0.43 \\
(0.46)\end{array}$ & $\begin{array}{c}0.28 \\
(0.29)\end{array}$ & $\begin{array}{c}0.29 \\
(0.25)\end{array}$ \\
\hline & 13 & Asp & $6.9_{6}$ & $6.1_{0}$ & - & $\begin{array}{c}0.40 \\
(0.41)\end{array}$ & $\begin{array}{c}0.32 \\
(0.34)\end{array}$ & $\begin{array}{c}0.28 \\
(0.25)\end{array}$ \\
\hline \multirow[t]{2}{*}{ Ac-Asp-NHMe } & 3 & Asp & $6.8_{3}$ & $5.1_{4}$ & $16.8_{5}$ & $\begin{array}{c}0.39 \\
(0.42)\end{array}$ & $\begin{array}{c}0.23 \\
(0.21)\end{array}$ & $\begin{array}{c}0.38 \\
(0.37)\end{array}$ \\
\hline & 7 & Asp & $8.3_{0}$ & $5.3_{7}$ & $15.9_{9}$ & $\begin{array}{c}0.52 \\
(0.57)\end{array}$ & $\begin{array}{c}0.25 \\
(0.30)\end{array}$ & $\begin{array}{c}0.23 \\
(0.13)\end{array}$ \\
\hline \multirow[t]{4}{*}{ Ac-Asp-Asp-NHMe } & 3 & $\mathrm{Asp}^{\mathrm{b}}$ & $7.5_{7}$ & $5.3_{7}$ & $17.0_{9}$ & $\begin{array}{c}0.45 \\
(0.49)\end{array}$ & $\begin{array}{c}0.25 \\
(0.27)\end{array}$ & $\begin{array}{c}0.30 \\
(0.24)\end{array}$ \\
\hline & & $\mathrm{Asp}^{\mathrm{C}}$ & 7.5 & $6.8_{0}$ & $17.0_{9}$ & $\begin{array}{c}0.45 \\
(0.47)\end{array}$ & $\begin{array}{c}0.38 \\
(0.44)\end{array}$ & $\begin{array}{c}0.17 \\
(0.09)\end{array}$ \\
\hline & 7 & $\mathrm{Asp}^{\mathrm{b}}$ & $6.5_{9}$ & $5.8_{6}$ & - & $\begin{array}{c}0.36 \\
(0.38)\end{array}$ & $\begin{array}{c}0.30 \\
(0.30)\end{array}$ & $\begin{array}{c}0.34 \\
(0.32)\end{array}$ \\
\hline & & $A s p^{c}$ & - & - & - & - & - & - \\
\hline
\end{tabular}

a Rotamer populations were obtained by Pachler's and Feeney's (in parentheses) approximation. ${ }^{25,26}$

b $\mathrm{N}$-terminal residue.

c C-terminal residue.

The rotamer population for Tyr shows little change and $P_{g^{+}}$for Asp decreased on deprotonation of Asp side chains in Ac-Asp-TyrNHMe and Ac-Tyr-Asp-NHMe, suggesting the absence of any particular (side chain)-(side chain) interactions. The ionization state of either side chain does not induce mutual conformational change in the side chains of these dipeptides. This is due to the bulkiness of the Tyr side chain which prefers the $\left(g^{-}\right)$-rotamer. ${ }^{27}$ No evidence for side chain interaction could be found from a rotamer analysis of the side chains in Lys-containing dipeptides. The results on the side chain conformation are still consistent even when Ac-Ser-Asp-NHMe and Ac-Asp-Ser-NHMe take on folded conformations.

\section{Interactions involving the Lys side chain}

Interactions between side chains were detected by ${ }^{13} \mathrm{C}$ relaxation measurements. $\mathrm{Ob}-$ servation of the ${ }^{13} \mathrm{C}$ relaxation greatly facilitated the motion analysis of the aliphatic residues in the peptides. ${ }^{28,29}$ The larger $T_{1}$ value corresponded to the greater mobility under the condition of extreme narrowing limit. Table $\mathrm{V}$ shows the $N T_{1}$ values of the individual carbons of Lys and Asp in AcAsp-Lys-NHMe and Ac-Lys-Asp-NHMe. Here, $N$ is the number of protons directly bonded to a given carbon. The $N T_{1}$ values for Lys gradually increase along the side chain from the $\alpha$ - to $\varepsilon$-carbons because of increase in mobility. The $N T_{1}$ value of the Lys $\varepsilon$-carbon is smaller in Ac-Lys-Asp-NHMe than in Ac- 
Conformation of Aspartic Acid-Containing Dipeptides

Table V. ${ }^{13} \mathrm{C} N T_{1}$ values in aqueous solution at $\mathrm{p}^{2} \mathrm{H} 7$ and $32^{\circ} \mathrm{C}^{\mathrm{a}}$

\begin{tabular}{|c|c|c|c|c|c|c|c|}
\hline \multirow{2}{*}{ Compound } & \multicolumn{5}{|c|}{ Lys } & \multicolumn{2}{|c|}{ Asp } \\
\hline & $\alpha$ & $\beta$ & $\gamma$ & $\delta$ & $\varepsilon$ & $\alpha$ & $\beta$ \\
\hline Ac-Asp-Lys-NHMe & 0.31 & 0.45 & 0.71 & 0.90 & 1.22 & 0.40 & 0.56 \\
\hline Ac-Lys-Asp-NHMe & 0.28 & 0.42 & n.d. ${ }^{b}$ & 0.82 & 1.04 & 0.29 & 0.40 \\
\hline
\end{tabular}

${ }^{\text {a }} N T_{1}$ values given in seconds. Errors in $N T_{1}$ are $\pm 10 \%$.

b Not determined.

Asp-Lys-NHMe, while the $N T_{1}$ values of Lys $\alpha$-carbon are comparable in both dipeptides within experimental error. The smaller $N T_{1}$ value indicates that the $\varepsilon$-amino terminal group is more constrained in Ac-Lys-AspNHMe than in Ac-Asp-Lys-NHMe. Furthermore, for Asp, the $N T_{1}$ values of $\alpha$ and $\beta$-carbons are smaller in Ac-Lys-AspNHMe than in Ac-Asp-Lys-NHMe by a factor of about 0.7 . These results may arise from the different degree of electrostatic attractive interaction between the Lys $\varepsilon$-amino and Asp carboxylate groups, which is greater in AcLys-Asp-NHMe than in Ac-Asp-LysNHMe. Although in an aqueous solution, intermolecular hydrogen bonding with water molecules competes with intramolecular interaction, the small differences in $N T_{1}$ values are still sufficient to account for the significant side chain interactions. The occurrence of side chain interactions is compatible with the proposal that the $\beta$-turn-like structure most likely occurs in Ac-Lys-Asp-NHMe.

The $\mathrm{p} K_{\mathrm{a}}$ value of the carboxyl group is known to be affected by the surrounding environment, e.g., intamolecular hydrogen bonding. ${ }^{30}$ Intramolecular hydrogen bonds which stabilize the carboxylate form should increase the acidity of the carboxyl groups. Table VI shows the $\mathrm{p} K_{\mathrm{a}}$ values of the Asp side chains obtained from titration curves for Asp $\beta$ carbons. These values are smaller in Ac-AspSer-NHMe, Ac-Ser-Asp-NHMe, Ac-AspLys-NHMe, and Ac-Lys-Asp-NHMe than Ac-Asp-Tyr-NHMe, Ac-Tyr-Asp-NHMe,
Table VI. $\mathrm{p} K_{\mathrm{a}}$ values of the carboxyl groups of aspartic acid residues

\begin{tabular}{cc}
\hline Compound & $\mathrm{p} K_{\mathrm{a}}^{\mathrm{a}}$ \\
\hline Ac-Asp-Ser-NHMe & 3.95 \\
Ac-Ser-Asp-NHMe & 4.05 \\
Ac-Asp-Tyr-NHMe & 4.15 \\
Ac-Tyr-Asp-NHMe & 4.45 \\
Ac-Asp-Lys-NHMe & 3.85 \\
Ac-Lys-Asp-NHMe & 3.90 \\
Ac-Asp-NHMe & 4.20 \\
Ac-Asp-Asp-NHMe & 4.00 \\
\hline
\end{tabular}

a Errors are $\pm 0.05 \mathrm{pH}$ unit.

Ac-Asp-Asp-NHMe, and Ac-Asp-NHMe by about 0.10 to $0.30 \mathrm{pH}$ units. These small but evident differences are quite consistent with the differences in degree of intramolecular interactions.

\section{Analysis Based on Chou and Fasman's $\beta$-Turn \\ Positional Potential}

From the above considerations, it may be concluded that the $\beta$-turn-like structure is preferable to Ac-Ser-Asp-NHMe and AcLys-Asp-NHMe with the deprotonated Asp side chain. Chou-Fasman's $\beta$-turn positional potentials for $\mathrm{N}$-terminal and $\mathrm{C}$-terminal residues are denoted by $P_{i+1}$ and $P_{i+2}$, respectively. These values are $P_{i+1}=1.27, P_{i+2}=2.06$ for Asp; $P_{i+1}=1.47, \quad P_{i+2}=1.32$ for Ser; $P_{i+1}=1.35, P_{i+2}=0.81$ for Lys; $P_{i+1}=0.79$, $P_{i+2}=1.24$ for Tyr. ${ }^{2}$ The $P_{i+1}$ values for Ser and Lys are larger than that of Tyr in the case of Ac-X-Asp-NHMe. This accords with the formation of the $\beta$-turn-like structure found 
in this paper. For the Asp residue, the $P_{i+1}$ value is smaller than the $P_{i+2}$ value. Indeed, no $\beta$-turn-like structure was found for Ac-Asp-X-NHMe. There is a correlation between the ability to form the $\beta$-turn-like structure and the $\beta$-turn potential within the dipeptides investigated here.

In regards to the (side chain)-(side chain) interactions, the degree of these interactions is also correlated to the $\beta$-turn positional potential. Each constituent $\beta$-turn positional potential of Ac-Asp-Ser-NHMe and Ac-Ser-Asp$\mathrm{NHMe}$, in which significant side chain interactions were found, is larger than that of Ac-Asp-Tyr-NHMe and Ac-Tyr-AspNHMe, in which no interactions occurred. More evident examples are the Lys-containing dipeptides. The product of the $\beta$-turn positional potentials of constituents, $P_{i+1} \cdot P_{i+2}$ and the degree of side chain interactions are larger in Ac-Lys-Asp-NHMe than in AcAsp-Lys-NHMe. Therefore the strength of the side chain interactions depends on the type of the amino acid residue as well as its sequence. These observations are consistent with the expectations based on Chou-Fasman's potentials.

According to the CPK molecular model, the two adjacent side chains come closer to each other in a folded conformation, particularly in most of the $\beta$-turn structures. From the above results, the $\beta$-turn structure is apparently stabilized more or less by interactions between the residue side chains located at the corner of the $\beta$-turn-like structure. This is also confirmed by the fact that deprotonation of Asp is necessary for (side chain)-(side chain) attractive interactions.

\section{CONCLUSIONS}

1. The $\beta$-turn-like structure is formed in Ac-X-Asp-NHMe ( $\mathrm{X}=$ Ser and Lys) with the deprotonated Asp side chain.

2. Besides the intramolecular hydrogen bond forming $\mathrm{C}_{10}$ structure, there are in- tramolecular interactions between the deprotonated Asp side chains and the side chains of the neighboring residues in Ac-Asp-SerNHMe, Ac-Ser-Asp-NHMe, and Ac-LysAsp-NHMe.

3. Good correlation exists between the strength of the side chain interactions and $\beta$ turn positional potentials.

4. The (side chain)-(side chain) interactions contribute to the stabilization of the $\beta$ turn-like structure.

Acknowledgements. We should like to express our sincere appreciation to NMR Appl. Lab., JEOL Ltd. for making the 200 and $270 \mathrm{MHz}$ NMR spectra measurements. Our sincere thanks are also due to Dr. Isao Ando, Tokyo Institute of Technology for allowing us use of the computer program, LAOCON.

\section{REFERENCES}

1. P. Y. Chou and G. D. Fasman, Biochemistry, 13, 222 (1974).

2. P. Y. Chou and G. D. Fasman, J. Mol. Biol., 115, 135 (1977).

3. K. D. Kopple and A. Go, Biopolymers, 15, 1701 (1976).

4. Y. V. Venkatachalapathi, B. V. Prasad, and P. Balaram, Biochemistry, 21, 5502 (1982).

5. K. Sato, M. Kawai, and U. Nagai, Biopolymers, 20, 1921 (1981).

6. G. Boussard, M. Marraud, and A. Aubry, Biopolymers, 18, 1297 (1979).

7. S. S. Zimmerman, L. L. Shipman, and H. A. Scheraga, J. Phys. Chem., 8, 614 (1977).

8. S. S. Zimmerman and H. A. Scheraga, Biopolymers, 16, 811 (1977).

9. F. Toma, H. Lamthanh, F. Piriou, M. Heindl, K. Lintner, and S. Fermandjian, Biopolymers, 19, 781 (1980).

10. S. K. Bramachari, R. S. Rapaka, R. S. Bhatnagar, and V. S. Ananthanarayanan, Biopolymers, 21, 1107 (1982).

11. B. V. Prasad, H. Balaram, and P. Balaram, Biopolymers, 21, 1261 (1982).

12. J. C. Howard, A. Ali, H. A. Scheraga, and F. A. Momany, Macromolecules, 8, 607 (1975).

13. R. Mayer and G. Lancelot, J. Am. Chem. Soc., 103, 4738 (1981).

14. A. Bundi, C. Grathwohl, J. Hochman, R. Keller, G. Wagner, and K. Wüthrich, J. Magn. Reson., 18, 191 


\section{Conformation of Aspartic Acid-Containing Dipeptides}

(1975).

15. A. Bundi and K. Wüthrich, Biopolymers, 18, 285 (1979).

16. R. Richarz and K. Wüthrich, Biopolymers, 17, 2133 (1978).

17. B. J. Dale and D. W. Jones, J. Chem. Soc. Perkin Trans. 2, 91 (1976).

18. J. Kobayashi and U. Nagai, Biopolymers, 17, 2265 (1978).

19. K. D. Kopple, M. Ohnishi, and A. Go, J. Am. Chem. Soc., 91, 4264 (1981).

20. T. Higashijima, T. Miyazawa, M. Fujino, and M. Wakimasu, Pept. Chem., 101 (1981).

21. Y. P. Pitner and D. W. Urry, J. Am. Chem. Soc., 94, 1399 (1972).

22. A. Demarco, M. Llinas, and K. Wüthrich,
Biopolymers, 17, 637 (1978).

23. G. N. Ramachandran and V. Sasisekharan, $A d v$. Prot. Chem., 23, 287 (1968).

24. J. Janin, S. Wodak, M. Levitt, and B. Maigret, $J$. Mol. Biol., 125, 357 (1978).

25. K. G. R. Pachler, Spectrochim. Acta, 20, 581 (1964).

26. J. Feeney, J. Magn. Reson., 21, 473 (1976).

27. K. Wüthrich and A. Demarco, Helv. Chim. Acta, 59, 2228 (1976).

28. T. Higashijima, M. Tasumi, T. Miyazawa, and M. Miyoshi, Eur. J. Biochem., 89, 543 (1978).

29. R. Deslauriers, I. C. P. Smith, and R. Walter, J. Am. Chem. Soc., 96, 2289 (1974).

30. C. A. Evans and D. L. Rabenstein, J. Am. Chem. Soc., 96, 7312 (1974). 